\title{
A felekezeti szakoktatás kihívásai a Partiumban ${ }^{1}$
}

\author{
Frigy Szabolcs \\ Babeș-Bolyai Tudományegyetem Szatmárnémeti Kihelyezett Tagozat
}

\begin{abstract}
A felekezeti és a szakoktatás az utóbbi idókig külön utakon jártak Erdélyben. A rendszerváltás után újra-induló magyar tannyelvü egyházi iskolák sajátos helyet foglaltak el a román oktatási piacon, a képzési kínálatuk teljesen az elméleti (teoretic ${ }^{2}$ ) osztályokra korlátozódott. 25 évvel az indulásuk után megváltozott a mikro- és makrokörnyezet, az erdélyi közösségben igény lett a szinvonalas magyar szakoktatásra, amelyet idóközben felkarolt Magyarország is. Az egyházi tulajdonban lévő épületek jó lehetöséget biztositottak az ilyen irányú infrastrukturális fejlesztéseknek is. A tanulmány ennek az átalakulásnak néhány sarkalatos pontját kivánja felvázolni és ismertetni a román oktatási rendszer sajátosságain keresztül.
\end{abstract}

Kulcsszavak: szakoktatás, felekezeti iskolák, Románia, szerkezeti átalakulás

\section{Felekezeti oktatás Romániában}

A felekezeti oktatásnak az anyaországon innen és túl más hangzása van. Romániában az iskolákat 1948-ban államosították, és az addig nagy múlttal rendelkező felekezeti oktatás egyik napról a másikra megszűnt. Az épületeket államosították, a tanárokat áthelyezték (176 sz. Rendelet, 1948. augusztus 3.) A kommunista emberideál és a diktatórikus berendezkedés nem türhette, hogy az egyházak értékorientáltan, vallásos szellemiségben neveljenek gyerekeket. Romániában ez a törekvés találkozott a kisebbségek asszimilációs törekvésével is, ezért kétszeresen fájó volt, hogy a bezárt iskolák helyett csak kis számban volt biztosítva a magyar anyanyelvü oktatás, főleg az elméleti líceumokban (gimnáziumokban).

Az 1989-es forradalom után nagy reményekkel tekintettek elöre a kisebbségek, és nagyon hamar megfogalmazódott az igény, hogy újraindítsák a felekezeti iskolákat. Egyrészt csalódás volt a demokratikus átrendeződés kisebbségi oktatáspolitikája (nem hozta el a várt eredményeket az anyanyelvű osztályok száma

\footnotetext{
${ }^{1}$ A tanulmány az MTA Domus Hungarica ösztöndíj támogatásával készült.

2 Kifejezetten érettségire majd egyetemi továbbtanulásra felkészítő osztályok, amelyek tudományterületen belül profilálódnak, például humán-teológia, társadalomtudományok, természettudományok stb.
}

alacsonyan maradt), másrészt az államosított épületek visszaadását remélték a felekezeti iskolák mihamarabbi megszervezésétől.

Minden erdélyi megyében a középiskolai osztályok beindítása volt a legfontosabb, hiszen az elmúlt évtizedekben a kisebbségi értelmiségi réteg kialakulását mesterségesen gátolták. A magyar anyanyelvű szakosztályok voltak többségben, és kevés érettségit biztosító osztály után még kevesebben tanulhattak egyetemen (Veres, 1998, 2000).

A felekezeti iskolák megszervezésének állami szabályozását úgy alakították ki, hogy az ortodox hagyományokat vették alapul, amelynek lényege, hogy az ortodox középiskolák kizárólag ún. kisszemináriumként müködtek, amelyek egyházi szolgálatra képeztek ki embereket. A papi szemináriumba tanulhattak tovább, de más felsőoktatási intézménybe nem jelentkeztek. Ez a hagyomány merőben eltért a katolikus, református, unitárius egyházak oktatási rendszerétől, amelyek keresztény szellemiségü értelmiségieket akartak képezni (akik később orvos, mérnök, tanárként állják meg a helyüket a világban, és így kapcsolódnak az egyházhoz).

Érthető volt az elégedetlenség, amikor csak teológiaosztályok indítását hagyták jóvá a 1991es kormányrendeletekben. Az első osztályok több helyen tiszta fiúosztályokként indultak, és úgy is került be a köztudatba, hogy ezek papnevelő intézmények (Bura, 2009, 2012). 
A felekezeti szakoktatás kihívásai a Partiumban

A felekezeti oktatás mindig komoly szerepet vállalt a társadalmi mobilitás elősegítésében. Olyan diákoknak is lehetőséget adott a továbbtanulásra, akik bár tehetségesek voltak, az anyagi helyzetük nem tette ezt lehetővé (Pusztai, 2004, 2011). A rendszerváltás után nehezen indultak (újra) a bentlakások és kollégiumok, amelyek pont a fent említett társadalmi mobilitást segítették volna és amely hozzáadott értéket tudott volna adni a felekezeti iskoláknak.

Ugyanakkor az egyházi javak visszaszolgáltatása sem indult be az elvárt módon, az új intézmények iskolához nem méltó helyen (pincékben, melléképületekben) kaptak helyet. Az iskolába járó vidéki diákokat román tannyelvü bentlakásokban tudták csak elszállásolni kifejezetten rossz körülmények között. A felekezeti iskolák bentlakásai, ahol egyházi szellemiségü nevelők dolgoznak még több évig nem tudtak megfelelő módon működni.

Jelen keretek között nincs lehetőség az egyes intézmények történetét külön-külön tárgyalni, de néhány közös elemet fontos kiemelni, amely sajátos társadalmi, politikai kontextusba helyezi majd az eredményeket.

A partiumi iskolatörténeteket vizsgálva jól látszik, hogy mindegyik intézményt „újraindították", megpróbálnak olyan történelmi gyökerekhez, intézményi kultúrához és narratívához visszakapcsolódni, amelyet fél évszázada megszüntettek. Ennek mindenhol fontos eleme az épület visszaigénylése és lehetőség szerinti birtokbavétele volt. Elmondható, hogy a rendszerváltás után majd tíz évvel szinte minden iskola a saját felekezetéhez tartozó, visszaszolgáltatott épületben müködik, még akkor is, ha nem a nagy múltú ingatlanban működnek (pl. a Hám János Líceum). Az épületkérdés bár lassan lezárulni látszik, mindenképp meg kell említeni a precedens értékű Székely Mikó Református Kollégium visszaszolgáltatását. 2012-ben egy peres eljárásban három hivatali személyt elítélték az állammal szembeni nagy értékű károkozás vádjával, mert a fent említett iskolát és épületet visszaszolgáltatták a református egyháznak. Az ügyben az indoklás a legfontosabb: nem volt jogos a visszaszolgáltatás, mert az épületet közadakozásból építették (a református egyházban jellemző módon), és mint ilyen állami tulajdonban kell, hogy maradjon. Az ügy még folyamatban van, erőteljes érdekérvényesítés mellett a hazai és nemzetközi sajtó és politikum is figyelemmel kíséri, hiszen széles körű hatásai lehetnek.

Lévén, hogy a felekezeti iskolák állami finanszírozással müködnek, mindig jelentős befolyása van az aktuális politikai konjunktúrának, az intézményeknek korlátozott autonómiájuk van, egyszerre kell megfelelniük az állami előírásoknak és a működtető felekezetnek is.

Közös jellemzője az iskoláknak, hogy a közeljövőben teljes iskoláztatást szeretnék biztosítani intézményeiken belül, óvodától középiskoláig. A hagyományoknak megfelelően az alulról való építkezésre törekszenek. $\mathrm{Ez}$ az épületben és nevelő személyzetben is folyamatos bővülést, változást jelent. Ezek a strukturális változások (főleg az előkészítő osztály bevezetésével) a közeljövőben finalizálódnak minden intézménynél.

A fenti tényezőkből adódóan és az intézményi kultúra fejlődésének szakirodalmát vizsgálva (ahol a nevelők fluktuációja negatívan hat az intézményi kultúrára; a vezető és a tíz évnél régebben tanító tanárok határozzák meg domináns módon a szervezeti kultúrát) elmondható, hogy a megszilárdulás időszaka még hátra van (Bacskai, 2008). A megszilárdulást gyengíti a jelenleg is érvényben lévő törvényi előírás, amely a centralizált számítógépes beiratkozás és leosztás révén (a nem teológiai profilú osztályokat jelenti) olyan diákokat helyez felekezeti iskolába, akik számára nem volt prioritás. Másrészről a teológiai osztályok kapcsán kicsi a társadalmi megbecsülés, jelentősen kisebb médiával jutnak be ide a diákok, megosztva az iskoláról kialakított képet. Ugyanakkor a törvény ennek a profilnak a megváltoztatására/elhagyására sem ad lehetőséget (ezen osztályok nélkül nem működhetnének állami vokacionális ${ }^{3}$ iskolaként).

\footnotetext{
3 A vokacionális tagozatot elhivatottsági vagy képességi tagozatnak lehet fordítani, illetve a Romániában élő magyarok egyszerüen csak magyarítják vokacionálisnak. A törvény szerint a vokacionális tagozatok a következő területeken indíthatóak: katonai (militar), teológiai (teologic), sport (sportiv), mủvészeti (artistic) vagy pedagógiai (pedagogic).
} 
Az intézmények újraalakulásakor fontos szempont volt a vidéki diákok felzárkóztatása, bentlakások kialakítása, továbbtanulásuk támogatása. Olyan társadalmi rétegnek kínált továbbtanulást, akik a kommunizmusban nehezen kerülhettek be elméleti oktatásba és tanulhattak tovább egyetemen. Sokáig úgy is élt a köztudatban, hogy ezek olyan iskolák, ahova azok járnak, akik nem jutottak be az elit iskolába, mintegy másodrangú elméleti líceumok. A negatív megítélést nagyban befolyásolta, hogy saját épület hiányában alig voltak láthatóak a helyi közösség számára. A 2000-es évek elején, tehát tíz évvel az indulás után kezdődött meg az iskolaépületek visszaszolgáltatása, és a felekezeti iskolák átköltözhettek.

\section{A felekezeti szakoktatás - egy új korszak kezdete?}

Az előző fejezetben már leírtam, hogy az 1990-es újraindulások időszakában fontos volt a múlthoz való visszanyúlás, amely tulajdonképpen legitimizálta is az intézmények létjogosultságát. Felekezeti oktatás sajátosan találkozik a kisebbségi létben való megmaradás kérdésével, még akkor is, ha a partiumi nagyvárosokban mindenhol van a felekezeti magyar középiskoláknak magyar nem-felekezeti alternatívája is. Míg a rendszerváltás után a szellemi elitréteg utánpótlása és a többségi társadalomhoz viszonyítva alacsony iskolázottsági mutatók javítása volt a cél, addig 25 évvel később, részben a demográfiai népességfogyásnak köszönhetően, hangsúlyeltolódások figyelhetőek meg.

A szakoktatást 2008 után új paradigmában szemlélik a politikusok, igaz ez Romániára ép úgy, mint az anyaországra is. A rendszerváltás utáni oktatáspolitika "mostohagyereke” a magyar szakoktatás, hiszen a kisebbségi politikának más prioritásai voltak. Míg önálló elméleti líceumokért harcolt a közösség, elfeledkezett a szakosztályokról, amelyek a kommunista időkhöz képest változatlanul működtek/működnek, román tannyelvű iskolákban, kisebbségi létmódban. Lévén, hogy a kevés osztály miatt fóállású szakembereket nem tudnak alkalmazni, a szaktantárgyakat románul kénytelenek tanulni, román tankönyvekből.

A szakoktatás két szinten történik. Választható egy 3 éves szakosztályos középfokú képzés, amely erősen gyakorlatorientált, sok iskolán kívül töltött gyakorló idővel, ám ez érettségit nem biztosít. Emellett létezik egy szaklíceumi képzés is, amely lehetőséget ad az érettségire, ám kevesebb idő jut gyakorlatra.

A Szatmár megyei helyzet tipikus minden nem tömbmagyarságban élő közösség számára. A magyar szakoktatás nagyon töredezett, ezért nem tud egységes klaszterként müködni, beletagolódnak a román tannyelvü intézményekbe. A 2014/2015-ös tanévben 114 induló osztályból, 32 volt magyar tannyelvü, ebből 14 osztály szakképzést biztosít, ám ez 8 különböző intézményben oszlik meg.

A romániai szakoktatás nincs könnyü helyzetben, számos rendszerszintű probléma van, ezeket kitűnően összegyűjtötték a Szakképzés, együttmüködés, társadalmi modernizáció - A romániai magyar szakképzés helyzetképe és fejlesztési lehetöségei című kötetben, amely a 2015-ös külhoni magyar szakképzés évének lezáró kiadványa az RMPSZ (Románai Magyar Pedagógusok Szövetsége) támogatásával született (Bíró, Bodó és BurusSiklódi, 2015)

A rendszer nagyon rugalmatlan, a bonyolult és költséges szakakkreditációk miatt az iskolák évekig nem változtatnak a képzési kínálaton és emiatt eltávolodnak a munkaerőpiactól. A képzések, amelyek müködnek, azok viszont korszerütlenek, a tanmühelyek elavultak a szektor alulfinanszírozottsága miatt. A szakok és intézmények annyira feldaraboltak, hogy javaslatok szintjén megjelenik a régiós magyar nyelvű szakképző intézmények kialakítása, amelyek korszerű felszereléssel, bentlakással látnák el a feladatot (Baranyai, 2015).

A több sebből vérző szakoktatás megoldása illeszkedik Magyarország nemzetpolitikai stratégiájába is. Az elmúlt években komoly dialógus folyt az oktatás és a gazdaság szereplőinek a bevonásával a helyzet megoldására. 
A felekezeti szakoktatás kihívásai a Partiumban

Ennek kiemelkedő része volt a már említett 2015-ös külhoni magyar szakképzés éve, de nem csak elméletalkotás szintjén foglalkoztak a témával, hanem a magyar állam több iskolát és tanmühelyt létesített vagy újított fel (pl. a kolozsvári Református Kollégium) és biztosít támogatást a jövőben induló osztályainak (pl. a szatmári Hám János Római Katolikus Teológiai Líceum).

\section{Fordulópont és új perspektívák}

A fent említett iskolastruktúra, amely a felekezeti oktatást vokacionális állami intézményként definiálja, új távlatokat kapott a 2015-ös év elején, amikor a történelmi egyházak egy-egy protokollszerződést írtak alá az Oktatási Minisztériummal, amely a 2011-es tanügyi törvény kötelező, de nagyban elkésett melléklete. Ebben elvi lehetőség nyílik minden szinten, minden típusú osztály indítására, amelyet jóváhagy a helyi tanfelügyelőség és a minisztérium (Frigy, 2017).

Az aláírt protokollszerződések egy meglévő helyzetet próbáltak meg szabályozni, mert az 1990-es iskolaalapítások után másfél évtizeddel a felekezeteknek kiterjedt iskolastruktúrával rendelkeztek, esetenként óvodától érettségiig, sőt jó néhány esetben már szakosztályokat is müködtetettek.

A híreket és a beiskolázási számokat figyelve nem lehet figyelmen kívül hagyni, hogy a 90-es években indított elméleti és teológiai profilú felekezeti iskolák elkezdtek nyitni a szakoktatás felé.

A következő táblázat a Szatmár, Zilah és Bihar megye felekezeti középiskoláinak IX. osztályos felvételi kínálatát összegezi:

\begin{tabular}{|c|c|c|c|}
\hline \multirow[t]{2}{*}{ Intézmény neve } & \multicolumn{3}{|c|}{ Képzés típusa } \\
\hline & Vokacionális & Elméleti & Szakképzés \\
\hline $\begin{array}{l}\text { Hám János Líceum } \\
\text { Szatmárnémeti }\end{array}$ & Teológia & Természettudomány & $\begin{array}{l}\text { - Elektronkai műszerész } \\
\text { - Szakács-pincér }\end{array}$ \\
\hline $\begin{array}{l}\text { Református Gimnázium } \\
\text { Szatmárnémeti }\end{array}$ & Teológia & $\begin{array}{l}\text { Matematika-informatika } \\
\text { Filológia }\end{array}$ & - Gazdasági szak \\
\hline $\begin{array}{l}\text { Kalazanci Szt. József } \\
\text { Nagykároly }\end{array}$ & Teológia & & - Élelmezés és turizmus \\
\hline $\begin{array}{l}\text { Lorántffy Zsuzsa } \\
\text { Nagyvárad }\end{array}$ & Teológia & & - Elektromosság \\
\hline $\begin{array}{l}\text { Szent László } \\
\text { Nagyvárad }\end{array}$ & Teológia & & $\begin{array}{l}\text { - Élelmezés és turizmus } \\
\text { - Gazdasági szak }\end{array}$ \\
\hline $\begin{array}{l}\text { Wesselényi Református } \\
\text { Gimnázium } \\
\text { Zilah }\end{array}$ & Teológia & $\begin{array}{l}\text { Matematika-informatika } \\
\text { Filológia }\end{array}$ & \\
\hline
\end{tabular}

1. ábra: A partiumi felekezeti intézmények oktatási kínálata a 2017-es tanévben (forrás: http://www.admitereliceu.ro)

Ki kell emelni, hogy a táblázat nem ragadja meg az időbeni átmenetet, amely minden intézménytípusnál sajátos életciklushoz kapcsolódik. Másrészt a szakoktatás formája (szakosztály vagy szaklíceum) különbözik az egyes intézményeknél.

A táblázatból kiolvasható, hogy a felekezeti iskolákban elmozdultak a szakoktatás irányába, érezhető egy nyitás és nyitottság. A változás iránya nem kizárólag oktatáspolitikai megfontolá- sokhoz köthető, váltást nem az indokolja, hogy az elméleti osztályok elnéptelenednének (bár a lokális oktatáspiacon soha nem voltak könnyű helyzetben), sokkal inkább az egyházak egy új „misszióként” tekintenek erre, amely sajátos társadalmi réteget akar felkarolni. Ezek a szakosztályok úgy vannak megszervezve, hogy egy szakma elsajátítása mellett nyitva hagyja vagy éppen feltételezi az érettségit is, így az egyetemi továbbtanulást sem zárja ki. 
A társadalmi felzárkóztatás ezen formája különbözik a rendszerváltást követő keresztény értelmiségit kitermelni vágyó törekvésektől, amellyel majd huszonöt év alatt többékevésbé elismert státuszt vívtak ki maguknak a régióban.

A váltást a partiumi intézményi struktúra is indokolja, ha nem is közvetlenül. A szakosztályok etnikai összetételének vizsgálata évek óta mutatja, hogy a magyar gyerekek egy része román szakosztályokban tanul tovább, ami sok szempontból problematikus. A román tannyelvü szakiskolákba integrált magyar tannyelvü osztályok nehezen tudják megjeleníthető módon képviselni identitásukat (pl. március 15. egy magyar tannyelvü intézményben ünnep, ahol a diákok ünnepi müsorral készülnek, ez egy vegyes tannyelvü iskolában nem elképzelhető).

A fent leírtakból nem evidensen következik, hogy miért pont egy felekezeti iskola, amely elméleti (theoretic) osztályokat müködtet, kell felkarolja a szakoktatást. Néhány pontban összefoglalhattam, hogy miért ilyen irányba indult el a magyar szakoktatás a Partiumban:

- A magyar állami segítség csak ott van biztonságban és ott kivitelezhető, ahol az épület egyházi kézben van és a fejlesztés célzottan a magyar diákokat érinti.

- A magyar osztályok szétszórtsága úgy enyhíthető, ha a meglévő teljesen magyar tannyelvü intézményrendszerhez kapcsoljuk valamilyen formában a szakképzést.

- A szakoktatás az elmúlt évtizedekben hatalmas bizalomvesztésen ment át, elvesztette presztízsét, ennek jó kompenzálása lenne a felekezeti jelleg, amely egy bizalomtöbbletet, vagy az elmúlt évek jó híréből táplálkozva egyfajta bizalomtranszfert jelentene.

A beiskolázási adatokat vizsgálva évenként látszik, hogy csak az elmúlt egy-két évben volt jellemző ez az irányváltás, és még csak az elején vannak ennek a változásnak, amely biztos nem lesz zökkenőmentes. Számos esetben a szakosztályok az elméleti osztályok kárára jöttek létre (nagykárolyi és váradi intézmények esetében). Mivel a diáklétszám folyama- toson csökken, nem lehet új osztályokat indítani anélkül, hogy valahol meg ne szünne egy másik. Az intézményi struktúra átalakításáról van szó, amelyet nem lehet gyorsan és körültekintés nélkül megvalósítani.

Az átalakulás több problémát is felvet:

- Minden intézménynek szüksége lesz a saját intézményi identitásának újragondolására, átfogalmazására. Talán „aktualizálni” kell a megváltozott külső (társadalmi) környezet kihívásainak megfelelően a küldetésüket.

- A tanárok saját maguk is át kell értelmezzék saját státuszukat (egy elméleti (theoretic) középiskolának nagyobb a társadalmi elismertsége, mint egy szakiskolának).

- Az iskola célcsoportja is megváltozik, ehhez pontos, világos üzeneteket kell majd megfogalmazni (kiket, miért milyen motivációval várunk stb.). A célcsoport kiszélesedik, vagy átalakul, a meglévő elméleti osztályokat választó családok mellé bekerülnek a szakoktatást választók, vagy az intézmény besorolása és kiterjesztett státusza negatívan hat majd a tiszta elméleti iskolát választó szülőkre (az én gyerekemet ugyanúgy ítélik meg, mint az ugyanoda járó szakosztályost). Tudjuk, hogy szociokulturális és gazdasági különbségek is vannak a különböző képzéstípus diákjainak családjai között (Dronkers és Avram, 2017).

- Mitől lesz felekezeti a szakoktatás? Milyen mértékben kell/lehet a már meglévő szokásrendet (kötelező lelki nap, heti istentisztelet/szentmise stb.) a szakosztályokra is kiterjeszteni?

- Együtt vagy külön? Egy épületben vagy külön kell-e elhelyezni a szak- és az elméleti osztályokat? Mindkét képzési iránynak sajátos igényei vannak.

A fenti folyamatot a közgazdaság és marketing világából kölcsönvett fogalommal „át kell pozicionálni", amely nem egy könnyü dolog, de minden esély megvan a sikerre.

\section{Összegzés}

A partiumi magyar felekezeti oktatás új kihívásokkal szembesült az elmúlt időszakban. 
A felekezeti szakoktatás kihívásai a Partiumban

A megváltozott demográfiai helyzet, a társadalmi elvárások és a lokális oktatási struktúrák átalakulása utat nyitott a szakoktatás irányába. Az új beiskolázási tervek egy kétpólusú képzési kínálatot tükröznek. Egyrészt megmaradnak az elhivatottsági, teológiai osztályok, amelyek törvényi alapot és létjogosultságot adnak az intézménynek, másrészt a hagyományos elméleti líceumi osztályok mellett/helyett megjelennek a szakosztályok is. Ez a folyamat egy valós közösségi igényre válaszol, hiszen a magyar szakoktatás nehéz helyzetben van ebben a régióban, a magyar egyházak társadalmi küldetésüknek érzik, hogy válaszoljanak erre az igényre. Másrészről az anyaországban is prioritás a szakoktatás kérdése, amely az országhatárokon átlépve az egyházi ingatlanokba való beruházással tudják segíteni a magyar nyelvű szakképzést.

A feladat azért nehéz, mert ahhoz, hogy sikeres legyen (például társadalmi, gazdasági, pedagógiai értelemben), tudni kell felülemelkedni a rendszerszintű problémákon. Míg az elméleti osztályok tekintetében „hozni kell a kötelezőt", addig a szakosztályoknál felül kell emelkedni, a meglévő tapasztalatokat átvéve, de azokkal nem megelégedve kell új pedagógiai rendszert építeni, az amúgy elég szűkös állami rendszerben. Bár a demográfiai adatok csökkenő létszámot mutatnak, a közösség bizalma adott a felekezeti intézmények irányába. Erre építve lehet elindulni a sikeres szakoktatás felé vezető úton.

\section{Felhasznált irodalom}

Bacskai Katinka (2008): Református iskolák tanárai. Magyar pedagógia, 108. 4. sz., 359-378.
Baranyai Tibor. (2015): Magyar nyelvü szakképzés a Partiumban. In: Bíró A. Zoltán, Bodó Julianna és Burus-Siklódi Botond (szerk.) Szakképzés, együttmüködés, társadalmi modernizáció - A romániai magyar szakképzés helyzetképe és fejlesztési lehetöségei. Alutus, Csíkszereda.

Bíró A. Zoltán., Bodó Julianna és Burus-Siklódi Botond (2015): Szakképzés, együttmüködés, társadalmi modernizáció - A romániai magyar szakképzés helyzetképe és fejlesztési lehetőségei, Alutus, Csíkszereda.

Bura László (2009): A megújuló egyház. Státus Kiadó, Csíkszereda.

Bura László (2012): Sakkfigurák. Státus Kiadó, Csíkszereda.

Dronkers, Jaap és Avram, Silvia (2017): Mit mutatnak a nemzetközi összehasonlítások az iskolaválasztás és a nem állami iskolák terén Európában? In: Bacskai Katinka (szerk.) A felekezeti oktatás új negyedszázada. Tanulmányok Pusztai Gabriella tiszteletére. Debreceni Egyetemi Kiadó, Debrecen, 97-116.

Frigy Szabolcs (2017): Az egyház és az állam közötti protokollszerződés a felekezeti oktatás rendezésére Romániában. In: Bacskai Katinka (szerk.) A felekezeti oktatás új negyedszázada. Tanulmányok Pusztai Gabriella tiszteletére. Debreceni Egyetemi Kiadó, Debrecen, 71-80

Pusztai Gabriella (2004): Iskola és közösség. Felekezeti középiskolások az ezredfordulón. Gondolat, Budapest.

Pusztai Gabriella (2011): Vallásosság és pedagógiai ideológiák. Educatio, 20. 1. sz., 48-61.

Veres Valér (2000): Nemzeti vagy nemzedéki integráció? Erdélyi középiskolások átalakulásban. Limes - Új Mandátum, Kolozsvár Budapest.

Veres Valér (1998): Pénz vagy tudás? A kolozsvári román és magyar egyetemisták társadalmi háttere és az értelmiségi utánpótlás sajátosságai. Korunk, 9. 6. sz., 26-36 


\section{Challenges of denominational vocational education in the Partium}

Denominational and vocational education have been separated in Transylvania until recently. After the fall of communism, Hungarian-language ecclesiastical schools re-started occupying a special place in the Romanian educational market, their training offerings were limited exclusively to theoretical classes. 25 years after the foundation of our school the microand macro environment has changed, in the Transylvanian community the high quality Hungarian vocational education has been demanded, which has in the meantime been underwritten by the Hungarian State. The buildings, which are in the possession of the Church offer a trustworthy possibility for such infrastructural developments as well. The aim of the study is to outline some fundamental points of that change and to present them through the peculiarities of the Romanian educational system.

Keywords: vocational education, denominational schools, Rumania, structural change

Frigy Szabolcs (2017): A felekezeti szakoktatás kihívásai a Partiumban. Gyermeknevelés, 5. 3. sz., $58-64$. 